\title{
Az íróinév-szótárak kérdései a tervezett Jókai-névszótár kapcsán
}

1. Az irodalmi múvek lexikográfiai feldolgozása és az írói nevek vizsgálata. Az íróinévszótár fogalmának tisztázásához mind névtani, mind lexikológiai, illetve lexikográfiai szempontból számos kérdéskört kell áttekintenünk az írói szótárak, a különböző névszótárak és mindenekelőtt az írói (irodalmi) névadás vizsgálatával kapcsolatban. A különbözö írók szókészletének és névrendszerének egyre szélesebb körü nyelvi, stilisztikai és pragmatikai vizsgálatát a mind magasabb mennyiségi és minőségi követelményeknek megfelelöen olyan komplex elemzés szolgálhatja a legsokoldalúbban, amely az összegyüjtött lexikális anyagot szótárszerüen dolgozza fel.

Az egyes írók és alkotásaik névrendszerének a valósághoz füződő viszonyát a magyar névkutatásból még hiányzó íróinév-szótár tárhatja fel a lexikográfia sajátos eszközeivel. Ennek lehetőségét, illetőleg az igényt egy ilyen szótár iránt már J. SolTész KATALIN megfogalmazta Arany János névvilágával kapcsolatban (1982), majd - részben innen merítve az ötletet - KorNYÁNÉ SzOBOSZLAI ÁGNES vázolta fel Németh László íróinév-szótárának elkészítésére vonatkozó tervét (1995). Sajnos ez utóbbi összegzés (az újabb javaslat szerint: névtár) egyelöre nem valósult meg (KoRNYÁNÉ 2014: 214), de a még korábban közzétett javaslatok mindenképpen megszívlelendők egy ilyen munka készítéséhez.

A következőkben elsősorban magyar tudománytörténeti adatok és kutatási eredmények tükrében igyekszem bemutatni az írói névadás, az írói szótárak, a névszótárak és az íróinévszótárak fő jellemzőit, rámutatva a nyilvánvaló összefüggésekre. Végül felvázolom egy íróinév-szótár, nevezetesen a Jókai-íróinév-szótár tervét, kijelölve a helyét az írói szótárak és a névtudományi munkák között.

2. Az írói névadás vizsgálatának szempontjai. Az írói vagy irodalmi névadás kutatásának áttekintése, a sokat vitatott müszóhasználat és a fogalmi kérdések problematikája (erről részletesen 1. T. Somogy 2015) fontos háttéranyagot jelentenek. Mindezek most csak annyiban érdekesek számunkra, hogy az írói nevek kapcsán felmerülö vizsgálati szempontokat mennyiben lehet és kell alkalmazni az íróinév-szótárak írásában, szerkesztésében.

2.1. A különböző névtani területek megjelenése az írói névadás vizsgálatában. Az irodalmi müvek alkotási folyamatában kiemelt szerep jut a névadásnak, egy-egy mü vagy író névrendszere kulcs lehet az értelmezéshez, a mondanivaló megértéséhez. Az irodalmi mủelemzés felöl közelítő magyar névtudományban KovalovszKy MiKLós volt az első, aki átfogóan tanulmányozta az írói névadás problémakörét (1934). A következő közel negyedszázadban csak a személynevek elemzésével foglalkoztak. Az irodalmi névkutatás további fejlődésére J. SolTÉSz KATALIN volt nagy hatással, aki tanulmányában (1958) elsőként hívta fel a figyelmet a helynévadás és az egyéb tulajdonnévfajták jelentőségére az írói nevek vonatkozásában.

Egy író életmüvében, vagy akár csak egyetlen irodalmi müben előfordulhat akár az összes tulajdonnévfajta is (vö. KORNYÁNÉ 2014: 211). A nevek vizsgálati lehetöségei tehát rendkívül 
tágak, de nemcsak a névfajták sokféleségéből adódóan, hanem azért is, mert a névtan különböző területein alkalmazott speciális szempontok és módszerek az írói névadás vizsgálatánál ugyancsak jól használhatók, sőt a megfelelő eredmény elérése érdekében kihagyhatatlanok.

Jelen áttekintésben elsősorban azok a szempontok érdemelnek figyelmet, amelyek a komplex elemzés lexikográfiai kapcsolatai felé mutatnak. Természetesen a kutató kitüzheti célul, hogy az elemzés során csak egyfajta névvel foglalkozzon, de szótári feldolgozáskor a cél általában egy-egy író vagy mủ teljes névrendszerének feltárása. Megjegyzendő, hogy a teljes névanyag vizsgálatának igénye a szakirodalom egészét tekintve viszonylag kevés feldolgozásra jellemző még értekezés formájában is. Az, hogy az egyes névfajták hogyan szerepelnek egy névszótárban, függ a szerkesztési elvektől, a szócikkek felépítésétől, viszont mind névtani, mind lexikográfiai szempontból alapvető követelmény, hogy a szócikkek szintjén megjelenjenek. A névfajták kategorizálási lehetőségeiről a szócikkek szerkesztésével kapcsolatban még lesz szó.

2.2. Az írói nevek viszonya a valósághoz. A legsajátosabb szempont az irodalmi müvek tulajdonneveinek vizsgálatában a nevek viszonya a valósághoz. Mindez szoros kapcsolatban áll az adott irodalmi mủ valóságábrázolásával, és függ az egyes irodalmi korszakok jellemzőitől is (vö. J. Soltész 1979: 153-172). A név és valóság viszonyában nemcsak arról van szó, hogy létezik-e, létezhet-e az adott név a valós névanyagban, hanem arról is, hogy beleillik-e az ábrázolt közösség vagy környezet valóságosan meglévő névrendszerébe, vagyis mennyire valószerü (akkor is, ha pusztán írói lelemény, és a tényleges névkincsben nem találjuk meg, legyen az személy-, hely- vagy egyéb névfajta).

A mủ elemzéséhez is elengedhetetlen megállapítani, hogy a benne elöforduló nevek közül melyek léteznek valójában, és melyek azok, amelyeket a szerző kitalált, költött. Sőt ezen túlmenően azt is vizsgálni kell, hogy a valós nevek tényleges denotátuma és a mübeli jelöltje milyen kapcsolatban van. A münek, illetőleg a szerzőnek a valósághoz való viszonya, illetőleg a valóságábrázolási szándéka is meghatározza, hogy csak fiktív, kitalált nevekkel dolgozik (olyanokkal, amelyekről egyértelmúen kiderül, hogy a valóságban nem fordulnak elö), vagy pedig olyan neveket alkalmaz, amelyek hitelesek (tehát a névkincsben fellelhető, létező neveket ad hőseinek, története helyszíneinek, vagy akár a valóságból emeli át hösei nevét az adott mübe). Általában a valóságos és a kitalált, de valószerü nevek váltakozása figyelhető meg; ezek egymáshoz viszonyított aránya a müre és a szerzőre egyaránt jellemző lehet.

Az irodalomtörténeti háttér feltárása elengedhetetlen a valóságos név viselöje, vagyis a modell és az irodalmi mű szereplöjének vagy helyszínének neve közötti összefüggések vonatkozásában (vö. J. Soltész 1979: 163; VITÁNYI 1982, 1985; K. SzoBoszlay 1992; VARGÁNÉ 2004; T. SOMOgYi 2007; VÁCZINÉ TAKÁCs 2018: 24-32). Fontosak lehetnek e tekintetben a kritikai kiadások jegyzetei, a keletkezéstörténetet bemutató tanulmányok, valamint azoknak az írói szótáraknak a megfelelő szócikkei, amelyek tartalmazzák a szerző müveiben fellelhetö tulajdonneveket is (vö. T. SомоGYI 2014: 168, 178).

A valóság és a fikció vonatkozásában meg kell említeni az ún. titkolózó neveket is. Ezek a csak (kezdö)betükkel jelölt, helyettesített vagy hiányos névformák (pl. T-ai Kármán József Fanni hagyományai címü regényében vagy $X$ vármegye, $Y$ vármegye Jókai Kárpáthy Zoltánjában) valamiféle átmenet irányába mutatnak a név elhallgatása, illetőleg a névtelenség felé (vö. FARKAS 2014: 133-134). Míg az utóbbiak értelemszerüen nem kaphatnak helyet egy szótári feldolgozásban, a titkolózó neveket érdemes szerepeltetni. 
2.3. Az írók névadási motivációi. Az a kérdés, hogy miért éppen az adott nevet választja az író - akár valóságos, akár kitalált névről legyen szó -, alapvető minden olyan névtani elemzés számára, amely nem csak a nevek összegyüjtésével, felsorolásával, illetőleg nem valamely speciális vagy névelméleti problémával foglalkozik. A névadási motivációk feltárása sokrétű feladat, és legtöbbször csak a vizsgált mü felől közelíthető meg, vagy esetleg az írónak több müvében elejtett megjegyzéseiből bontható ki (vö. ÁDÁm 1992, SzATHMÁRI 1993, KoRNYÁNÉ 1997, PÁJ 2014). Természetesen előfordul, hogy valamely író nyilatkozik, vagy például naplójában, levelekben vall az egy-egy hőse számára választott névről. Ezeket a megnyilatkozásokat a kritikai kiadások jól fel tudják használni a szövegkritikai apparátusban, és minden bizonnyal lehet rájuk utalni az íróinév-szótári szócikkek megfelelö részében is.

Az irodalmi névadás kutatásának kezdeteitől a középpontban volt a névadási motiváció mint a névadás folyamatának kiindulópontja. Sokszor a névhangulat, a különböző asszociációk és a névjelentés felől közelítették meg a kérdést. A kor névízlésének és névdivatjának felderítése ugyancsak névtudományi feladat, amelynek jelentőségére már KovalovszKY (1934) és J. Soltész (1964) is felhívta a figyelmet. A megfelelő motiváció kifejtése a szócikkek értelmező részében jól elhelyezhető, és rendkívül informatív lehet.

2.4. A tulajdonnév mint stíluseszköz. Az ábrázolás és a jellemzés, sőt a korfestés is történhet a tulajdonnevekkel akár direkt, akár látens módon. Az író névhasználata ebből a szempontból írható le a legérzékletesebben. Ebböl következik, hogy a nevekkel kapcsolatba hozható stilisztikai eszköztárat a stílusminősítésekhez kapcsolódóan érdemes beépíteni a névszócikk törzsébe.

Előfordul, hogy a költő valamely tulajdonnevet stilisztikai alakzatként alkalmaz. Ilyen a névmetafora vagy antonomázia, amelynek előfordulását KORNYÁNÉ vizsgálta Petőfinél (2008). Figyelembe vehetők, illetve felhasználhatók más személynevekkel kapcsolatos, stílushatással, stilisztikai eszközökkel foglalkozó kutatások is (pl. BüKY 1989, 2008; Heltainé Nagy 1998, 2010).

Az író stílusát, korát legjobban jellemzik a motivált név kifejezéssel összefoglalható írói nevek. Ezek archetípusa a beszélő név, de ebben a körben a legátlátszóbb és nyilvánvalóan költött nevektől az utalásos valószerü vagy akár ténylegesen létező, de egyértelmü asszociációkat keltő nevekig minden megtalálható (vö. T. SoMOGYI 2015: 214). Ezt a vonatkozást az adott szócikkekben mindenképpen jelölni kell, ugyanúgy, mint a névhez kapcsolódó humor és irónia kifejezését.

3. Írói szótáraink és fóbb típusaik. Az írói szótár az adott mü, illetőleg szerző lexikai anyagának stilisztika-központú feldolgozása. Az így létrejött munkák sokfélék lehetnek, mivel a különböző célú és igényü írói szótárak a feldolgozott müvek, életművek tekintetében nagyon eltérőek. A vizsgált korpusz mennyiségétől, a feldolgozás tárgyától, módjától, a vizsgálat és a felhasználás céljától és - nem egyszer - a lehetőségektől függően különböző típusokat képviselnek.

Tudjuk, hogy már a 19. század végétől felmerült az igény, hogy jelentős íróink, költőink szókincsét szótárakba gyüjtsék, szavaikat elemezzék. Eleinte csak szómutatók, esetenként szemelgető szótárak készültek. A kezdetekről részletesen először WACHA IMRE írt a PetőfiSz. munkálatainak indulásakor 1961-ben.

A magyar írók müveit, életmüvét felölelő szótárak, szótárjellegü adattárak, konkordanciák az utóbbi évtizedekben gyarapodnak, bár hiányok még mindig vannak bőven, amelyek 
felsorolására itt most nem vállalkozom. Az írói szótárak általános kérdéseivel és az idetartozó mủvek számbavételével a magyar szakirodalomban elsőként BENKŐ LÁszLó foglalkozott 1979-ben megjelent monográfiájában. Azóta hasonló méretủ átfogó mủ nem született a kérdéskörrel kapcsolatban. Újabb szótári munkák kiadása és tervei kapcsán BüKY LÁszLó 2010-ben, majd MÁRTONFI ATTILA 2014-ben tekintette át röviden a magyar írói szótárak sorát.

Szempontjaikat némileg módosítva a következőkben számba veszem a legjelentősebb idetartozó munkákat. Kitérek arra is, hogy az egyes szótárak, illetőleg szerkesztőik hogyan kezelték az írók által használt tulajdonneveket, e kérdéskörrel utalva a tervezett íróinévszótárak szerepére.

3.1. Szótár jellegű adattárak, konkordanciák. Ebben a típusban az egyik legismertebb a CsokSzkt. Külön kötetekben dolgozták fel Csokonai színmüveinek és prózai műveinek, valamint költeményeinek a szókincsét. A Radnóti Miklós verseiből készült interaktív konkordancia szótár az informatika és a lexikográfia találkozásának beláthatatlan lehetőségeire hívja fel a figyelmet (BODA-PoRKolÁB 2009-2012). A szerzőpáros egyéb munkái is az irodalmi szövegek számítógépes feldolgozását mutatják be a szövegértelmezés új útjait járva. Itt érdemes megemlíteni a kódexek szóanyagát betürendbe soroló munkákat is, de írói szótárnak ezek semmiképpen sem tekinthetők, inkább elsősorban nyelvtörténeti adattárak (vö. MÁRTONFI 2014: 31).

3.2. Értelmező típusú írói szótárak. A felhasználók szempontjából ez a legkeresettebb típus. Nemcsak az előfordulásokat és az esetleges alakváltozatokat közli, hanem legtöbbször stílusminősítést is, és megadja a címszó jelentését, jelentésstruktúráját, ami az író müveinek vagy egy adott alkotásának megértése szempontjából sokszor nélkülözhetetlen. Ide tartozik a JuhászSz., a ToldiSz., a PetőfiSz., a BánkBSz., a ZrínyiSz., a RadnótiSz. és az AranySz., továbbá részben a BalassiSz., valamint a JókaiSz. is.

3.2.1. Teljes vagy részleges írói szótárak. Az értelmező jellegủ írói szótárakon belül a feldolgozott szókincstől függően megkülönböztetjük azokat, amelyek a teljes életmüvet, és azokat, amelyek csak egy, esetleg több összefüggő alkotást dolgoztak fel. Ebben a megközelítésben teljes írói szótárnak számít a már említettek közül a PetőfiSz., a BalassiSz. és a ZrínyiSz. Valójában teljesnek azonban csak a PetőfiSz. tekinthető, mert a BalassiSz. csak a versek szókincsének szótára, a levelezés és a műfordítások szóanyagát függelékben, szóalakmutató formájában közli, a ZrínyiSz. pedig nem tartalmazza az idegen szavakat és a tulajdonneveket sem. (A teljes életmüvet közlő CsokSzkt. csak konkordanciaszótár, így tárgykörünkön kívül esik.)

A JuhászSz., a RadnótiSz. és az AranySz. csak a költői művek szókincsét szótárazza, a ToldiSz. és a BánkBSz. pedig csupán egy-egy jelentős alkotást dolgoz fel szótári formában. A JókaiSz. csak azon regények, elbeszélések magyarázandónak itélt szóanyagát tartalmazza (alapvetően tulajdonnevek nélkül), amelyek az Unikornis Kiadó által megjelentetett Jókaisorozat első száz kötetében találhatók, bár a címszók száma így is majdnem eléri a 25 ezret.

3.2.2. Az írói szótárak és a filológiai szempontok. Ahogy e problémakörről már korábban írtam (vö. T. SOMOGYI 2014: 168-169), a teljesség vagy részlegesség kérdése mellett elsősorban az értelmező típusú írói szótáraknál fontos, hogy tudományos, szakmai céllal íródtak-e, vagy a nagyközönség számára készült, ún. népszerü kiadványok. Ez utóbbira 
a legjobb példa a JókaiSz., amelyben sem lelöhely, sem előfordulásszám nem szerepel, valamint példamondatok sem. Mindez a kutathatóságban komoly hátrányt jelent, de eddig még nem vállalkozott senki a Jókai-müvek teljes, szövegkritikailag korrekt feldolgozására.

A leginkább tudományosnak nevezhető a PetőfiSz. és a ZrínyiSz., amelyek igyekeznek megfelelni a szigorú filológiai szempontoknak. Természetesen a többi, már említett szótárban is fontos a közölt adatok pontossága, és lehetőség szerinti visszakereshetőségük, de ahhoz, hogy az ilyen jellegü munkák az oktatásban is jól használhatóak legyenek, a túlrészletezett vagy túlkódolt adatközléstöl el kellett tekinteni például a ToldiSz. és a BánkBSz. esetén is.

3.2.3. A digitális írói szótárak. A szótárkészítés módját tekintve a nagy áttörést a digitális szótárak jelentik. Míg korábban készült írói szótárainkat a korabeli technikai színvonalhoz igazodva a müvekből kicédulázott anyagból szerkesztették akár több évtizedig tartó munkával (pl. PetőfiSz.), az újabban összeállított szótárak létrehozásában már számítógépes segítséget vettek igénybe nemcsak az adattárakhoz, hanem a különböző célprogramok megalkotásával a szerkesztési folyamatban is. Ennek eredményeképpen a CsokSzkt. és a BalassiSz. nemcsak nyomtatásban, hanem online is elérhető, a BODA-PORKOLÁB-féle Radnóti-konkordancia pedig alapvetően internetes felületen tanulmányozható ugyanúgy, ahogy a szerzőpáros egyéb íróikonkordancia-szótárai (vö. T. Somogyi 2014 : 169).

A folyamatosan bővülő MikesSz. már valódi digitális szótár, annak minden előnyével. Az adatközlésben nincsenek terjedelmi megkötések, az összefüggések, kapcsolatok az informatikai háttérrel gyakorlatilag korlátlanul feltárhatók. Erre a 1,5 millió szövegszóból álló korpusz esetén feltétlenül szükség is van (Kiss 2012). Egy ilyen szótár elkészítéséhez is rengeteg manuális és szellemi munka szükséges. A szótárszerkesztési elveket, a címszavasítást, a paradigmasorokat, az alakváltozatokat a számítógép sem kiválasztani, sem előállítani nem tudja a lexikográfus alkotómunkája nélkül. A programkészítő szakemberek is csak megfelelő nyelvészeti szakmai irányítással tudják azokat az eredményeket elérni, amelyek révén a szótárkészítés megvalósítható. Az írói szótárak esetében ráadásul még azzal is számolni kell, hogy minden írói (élet)mü sajátos megközelítést igényel, vagyis a szerkesztő irodalomtörténész is egyben. Csak remélhetjük, hogy a régóta tervezett következő digitális írói szótár, a József Attila-szótár előbb-utóbb elkészül (vö. MÁRTONFI 2014).

3.3. A tulajdonnevek az egyes írói szótárakban. Köztudott, hogy eddig a PetőfiSz. az egyetlen elkészült és befejezett, a szó valódi értelmében teljes írói szótár, amely a szerző minden egyes leírt és ránk maradt szavát feldolgozta, az idegen szavakkal és a tulajdonnevekkel együtt. Ugyan vannak olyan írói szótárak, amelyek mellőzik a tulajdonnevek felvételét, de a többségükben szerepelnek hely-, személy- vagy állatnevek, viszont a megjelenítés módjában adott szótárakban esetenként jelentős különbségeket tapasztalhatunk. Jellemző lehet, hogy a tulajdonneveket szófaji minősítéssel megkülönböztetik-e a köznevektől, és az is lényeges, hogy milyen címszóstruktúrába illesztik be őket, és mennyire tagolt a jelentésszerkezetük. Erről a témakörről korábban részletesen írtam (vö. T. SoMOGYI 2014). Arról, hogy a tulajdonnevek írói szótári kidolgozása nem jelentheti valamiféle kisenciklopédia összeállítását, MÁRTONFI AtTILA (2015) is kifejtette a véleményét.

3.3.1. Címszóválasztás és tulajdonnév. Abban a vonatkozásban, hogy egy-egy írói szótár készítői hogyan viszonyulnak a különböző tulajdonnevekhez, az elsődleges kérdés az, hogy ezeket felveszik-e a címszók és ezáltal a szócikkek közé, vagy mellözik őket. 
Ez utóbbi megoldásnak is több oka lehet. A tudományos igényü ún. teljes szótárak közül a ZrínyiSz. az, amelyik kihagyta a tulajdonneveket, nem tekintve öket a szókincs részének. A Jókai-szótár mint népszerü szómagyarázó szótár azért nem vállalta fel a tulajdonnevek értelmezését, mert sokszor óhatatlanul lexikonszerü megoldásokat kellett volna alkalmaznia, például egy-egy történelmi személy vagy mitológiai alak, bibliai vagy történelmi helynév azonosításakor, értelmezésekor. Ráadásul a szótár készítésekor fennálló komoly terjedelmi és időbeli korlátok is a tulajdonnevek kihagyása mellett szóltak.

3.3.2. A tulajdonnévi címszók kialakítása. Azokban a szótárakban, szótár jellegű adattárakban, amelyekben a tulajdonneveket megtaláljuk a címszólistában, a tulajdonnévi címszók kialakítása, ,szinkronizálása” a köznévi címszókkal annak megfelelően történt meg, hogy a szerkesztők mennyire akarták érvényesíteni a tulajdonnevek nyelvhasználati (szemantikai és pragmatikai) sajátságait és szófajspecifikus jegyeit (T. SoMOGYI 2014: 173). Mindez egyértelmüen kiderül, ha például a PetőfiSz., a ToldiSz., a BalassiSz. vagy a MikesSz. tulajdonnévi szócikkeit összehasonlítjuk. Ez utóbbi szóanyagának címszavasítása során világossá vált, hogy a szókincs részének tekintendő tulajdonneveknél a megfelelő címszó felvétele még nagyobb odafigyelést igényel, mint a közneveknek, illetőleg a szókészlet egyéb elemeinek esetében. A többi szóegyeddel összhangban a személy- és helyneveknél is meg kellett határozni a ma leginkább használatos alakot mint lehetséges címszót, de ebben gyakran enciklopédikus ismeretek, illetőleg a bibliai és különböző antik vagy egyéb történeti források is segítettek azon túl, hogy a lexikográfiai gyakorlatnak megfelelően a korpuszban előforduló variánsokat is figyelembe kellett venni. Az írói szótárakban fellelhetö tulajdonnévi címszók, illetőleg szócikkek tanulmányozása nagyban segítheti az íróinév-szótárak szerkesztési elveinek kialakítását.

4. A névszótárak és az írói nevek. Azoknak a szótáraknak a körébe, amelyekben a címszók csak tulajdonnevek, tartozhatnak régi névszótárak, onomasztikonok, szótárszerü névfeldolgozások és valódi íróinév-szótárak. Ezek mind összefüggésbe hozhatók a tervezett Jókai-névszótárral; részben mint előképek, részben mint ötletadók.

Legutóbb FARKAS TAMÁS (2020) foglalkozott átfogóan a névszótárakkal, illetve általában a nevek szótári feldolgozásának lehetőségeivel. Végiggondolva a névszótárak kapcsolatát az írói nevekkel, ehhez az alapos elméleti igényü áttekintéshez füzök hozzá néhány, az íróinév-szótár tárgykörére vonatkozó kiegészítést.

Az egyértelmü, hogy a különböző nevek szótárba gyüjtése, rendezése számos eltérő szótártípust eredményez attól függően, hogy mely névfajtákat tartalmazza, és hogy milyen célból szerkesztették öket egybe. A nevek számbavétele, összegyüjtése és közzététele legegyszerübben szótári formában történik, és egyre több olyan munkát találunk, amely valamilyen speciális névanyagot tartalmaz. A gyüjtés szempontjai sokfélék lehetnek, és ezek az újabb, szótári felépítésủ névtárak rendkívül fontos és hasznos háttérként szolgálhatnak akár írói névadáshoz, névalkalmazáshoz is. A névtár terminus általában nem helyettesítheti a névszótár megjelölést, mert a névtár elsősorban adattárnak minősíthető, a szótár viszont értelmezést, magyarázatot, szófaji vagy stílusminősítést és különféle többletinformációt is tartalmaz. Természetesen esetenként az egyszerübb névtárak is összefüggésbe hozhatók az irodalmi névadással, de szerkezeti szempontból inkább a gazdagabb tartalmú névszótárak mint források adatai bukkanhatnak fel egy-egy írói müben. (Például egy író ötleteket meríthet egy helynévtár vagy egy keresztnévszótár anyagából.) 
Az íróinév-szótárak alapvetően tehát az írói névadás feldolgozására hivatottak, és szócikkeikből kell, hogy összeálljon az adott író életmüvének vagy egy-egy alkotásának, esetleg egy irodalmi közösségnek a névrendszere.

4.1. Régi írói névszótárak - enciklopédiák. Ugyan alapvetően a készülő magyar íróinév-szótárak előzményeit, kapcsolatait törekszem bemutatni, de a kép árnyalásához érdemes egy kis kitérőt tenni, röviden említve két angol nyelven író egykori tudós szótárszerző munkáját.

4.1.1. Bibliotheca Classica. JoHn Lemprière angol klasszika-filológus, teológus, lexikográfus müve 1788-ban jelent meg Readingben. Alcíme (Classical Dictionary containing a full Account of all the Proper Names mentioned in Ancient Authors) pontosan leírja, mit is tartalmaz ez a sokáig közkedvelt kézikönyvként használt szótár vagy inkább lexikon: az összes klasszikus ókori szerző által leírt tulajdonnév össze van gyüjtve benne. A bevezetö szerint a munka célja az volt, hogy a lehető legpontosabban számot adjon a klasszikusok olvasásakor előforduló valamennyi névről, valamint a hozzájuk füződő mitológiai vonatkozásokról és történelmi tényekről. Mindezek mellett tanulságos és szórakoztató módon kíván átfogó képet rajzolni az ősi időkről. A szótár népszerüségét és közismertségét hangsúlyozva több helyen is említik, hogy John Keats is mint egyik legkedveltebb könyvét jelölte meg. LEMPRIẺRE jól ismerte és valószínüleg munkájához felhasználta SAMUEL JOHNSON híres angol szótárát, az A Dictionary of English Language-et, amely 1755-ben jelent meg, óriási hatást gyakorolva az angol lexikográfiára.

4.1.2. A Dictionary of Scripture Proper Names. James Beaumont Jackson amerikai tudós szótárát tizenegy éves kemény munkát követően először 1909-ben tette közzé Bostonban. A szótárban 3500 bibliai nevet találunk előfordulási helyük megjelölésével, alfabetikus sorrendben. A szerző angolra fordítva nemcsak értelmezi őket, hanem mindegyikhez részletes névmagyarázatot is ad. Célja, hogy az olvasók pontosabban érthessék a tanításokat, jobban eligazodjanak a bibliai történetekben. A közkedvelt münek 2016-ban elkészült a reprint kiadása, sőt online is hozzáférhető.

4.2. Az írói nevek mai feldolgozása szótárszerűen. Olyan, az íróinév-szótár müfajához közel álló munkákat érdemes még említeni, amelyek vagy egy író alakjainak, vagy egy müfajban megjelenő szereplőknek, vagy általában irodalmi hősöknek a nevét veszik számba. Az említendő munkák közös jellemzője, hogy csak személynevek szerepelnek bennük címszóként, hely- és egyéb nevek nem tartoznak a tárgykörükbe.

4.2.1. A Tótfalusi-kötetek. A következőkben mindenképpen foglalkozni kell TóTFALUSI IsTVÁNnak az irodalmi művek személynévanyagát feldolgozó, elsősorban a műelemzés felől közelítő köteteivel, amelyek lexikográfiai értelemben nem szótárak, inkább - mint a címük is mutatja - ismeretterjesztő igénnyel összeállított lexikonok. A névtani szempontok nem játszanak szerepet, a névadás kérdése sem kap hangsúlyt, elsősorban irodalmi, müelemzési szemszögből tárgyalja az egyes irodalmi hősöket nevük betürendjében. A szócikkek általában 10-60 sorban leírják az adott figura szerepét a cselekményben, valamint a többi alakhoz való viszonyát is. 
A sort az 1992-ben megjelent Irodalmi alakok lexikona nyitotta. Sikerét mutatja, hogy 1994-ben újra kiadták, majd 1998-ban bővített kiadásra is volt igény. Közben elindultak a Ki kicsoda kötetek is: Ki kicsoda az antik mítoszokban? (1993), Ki kicsoda Shakespeare világában? (1994a), illetve Ki kicsoda Shakespeare müveiben? (1994b), Ki kicsoda a Bibliában? (1995).

Az eredetileg háromkötetesre tervezett Irodalmi alakok nagy lexikona (2010-2011) 1. kötete a mítoszok és mondák, a 2. a magyar irodalom alakjaival foglalkozik. A világirodalmi tárgyú 3. kötet sajnos már nem készülhetett el. A müelemzésekhez is használható magyar irodalmi szócikkek széles körből merítenek, 110 szerző 222 müvében szereplö 1350 irodalmi alak kapott szócikket, természetesen közöttük Jókai több regényhőse is.

4.2.2. A Beckett-onomasztikon. JEREMy PARRotT angol nyelvü müvének (Change all the names: a critical onomasticon of characternyms in the works of Samuel Beckett) több szempontból is helye van az irodalom-központú szótárszerü névtani munkák között, ráadásul magyar vonatkozása is van: 2004-ben Szegeden jelent meg. A müfaji megjelölése onomasztikon, müvek szerinti betürendes feldolgozás. PARROTT a teljes becketti életmü feldolgozására vállalkozott, ennek eredménye a több mint 650, Beckett alkotta szereplö nevének hosszas és részletes elemzése, a névadási motivációra összpontosítva. Mindemellett a szerző az írói névadás kérdéseiröl is értekezik a kötetben (vö. FARKAS 2006).

5. A tervezett Jókai-névszótár. Néhány évvel ezelőtt úgy tünt, hogy a minimális személyi feltételek adottak ahhoz, hogy lelkes hallgatókkal együtt az ELTE Bölcsészettudományi Karán a névtudományi diákmühely égisze alatt elindítsuk a Jókai-regények névanyagának próbagyüjtését, és összeállítsuk a próbaszócikkeket. Sajnos, időközben a személyi állományban is változások következtek be, és nyilvánvalóvá vált, hogy komoly pályázati támogatásra is szükség van a nagyobb elörelépéshez, és természetesen stabil informatikai háttérre. Az eddigi munka során felmerült kérdésekről, a még alakulóban levő gyüjtési és szerkesztési elvekről adok számot a következőkben, bízva abban, hogy a tervek a nehézségek ellenére megvalósulnak.

5.1. A (szak)irodalmi előzmények. A Jókai-életmű szótári feldolgozásának ötlete már korán felvetődött (vö. Somogyi 1917), később GodA GÉzA egy Jókai-szó- és szólástár előkészületeiröl számolt be (1951).

Végül 1994-ben ténylegesen elkészült egy kétkötetes szótár, az Unikornis Kiadó Jókaisorozatában addig tervezett 100 kötet szókincse alapján. Mint már említettem, közel 25 ezer címszót tartalmaz úgy, hogy sem az alapszókincs elemei, sem tulajdonnevek nincsenek benne, „csupán” azok a régi, elavult, nyelvjárási, idegen és egyéb szokatlan jelentésben használt szavak, kifejezések, amelyeket a szótár szerzői az olvasók szempontjából magyarázandónak ítéltek. A szótár erényeiről és hibáiról a Jókai-kutató NAGY MikLós is írt részletesen (1995).

Különböző számítások alapján azt feltételezzük, hogy közel 50 ezer címszó lenne egy ún. teljes Jókai-szótárban, természetesen utalók nélkül, vagyis 50 ezer tartalmas szócikket kellene megszerkeszteni. Az eddig elkészült vagy készülőben levő írói szótárak terjedelmi kérdéseivel már korábban foglalkoztam (T. SOMOGYI 2014: 170-172), és az ott közölt ábrák alapján nyilvánvaló, hogy mind a várható szócikkmennyiség, mind a feldolgozandó, közel 10 millióra becsülhető adatszám (vö. WACHA 1994: 440) jóval meghaladja bármelyik szótár hasonló mutatóit. Bár a PetőfiSz. a félmilliós és a MikesSz. a másfélmilliós 
szövegszószámával jelentősen kiemelkedik a többi szótár közül, a Jókai-korpusz nagyságát még csak meg sem közelítik.

A tervezett és előkészületben levő Jókai-névszótár címszóanyaga alapvetően eltér a jelenleg rendelkezésünkre álló JókaiSz.-étól, amelyből a tulajdonnevek lényegében kimaradtak. A névszótár elkészítéséhez fontos háttéranyagot biztosítanak a névelméleti munkák mellett a Jókai névadását, névalkalmazását bemutató elemzések, amelyek általában egy vagy több regény névkincsét tekintették át, főleg a személynevek szempontjából (pl. KAPOSI 1985; KUTASI 1991; NAGY 1999, 2001a, 2001b; KÉFER 2001), bár született kimondottan a helynevekkel kapcsolatos tanulmány is (T. SOMOGYI-TINER 2017). Esetenként a kritikai kiadások jegyzetanyaga és egyéb textológiai kutatások eredményei is jól hasznosíthatóak. Érdemes odafigyelni a névváltoztatásoknak és a Jókai alkotta neveknek a családnév-változtatásokra való hatását (FARKAS 2007), illetőleg a Jókai-müvekben megjelenő névváltoz(tat) ásokat (T. Somogyi 2009: 316-319) vizsgáló munkákra is.

Figyelmet kell fordítani a frissen megjelent Jókai-enciklopédia (BALÁzsI-Kiss 2020) anyagára is, bár e munka jellegéből adódóan inkább a Jókai-müvek háttéranyagát és nem a Jókai-névrendszert igyekszik bemutatni.

5.2. A gyüjtés kérdései, feladatai. A Jókai-életmü rendkívül nagy: az 50 éves írói jubileumára 1894-1898 között megjelentetett 100 kötetes nemzeti díszkiadás is ezt volt hivatott érzékeltetni. Az Unikornis Kiadó 1992-től 2005-ig 116 kötetben adta ki Jókai müveit gyüjteményes díszkiadásként. A teljes életmüvet tekintve ez a sorozat sem nevezhetö hiánytalannak, de az egyértelmü, hogy a WACHA IMRE által közölt, korábban említett 10 millió szóadat egyáltalán nem túlzás. Az anyag nagy része digitális formában is hozzáférhető: Jókai Mór összes müvei [!] címen az Unikornis-sorozat 100 kötetének teljes szövegét CD-ROM formájában megjelentette az Arcanum Kiadó 2001-ben. A kritikai kiadások szövegei a Magyar Elektronikus Könyvtárban is kereshetök.

Nyilvánvaló, hogy a terjedelmet illetően nagyságrendekkel jobb a helyzet, ha csak a tulajdonneveket akarjuk kigyüjteni. Azt viszont ebben az esetben is alaposan át kell gondolni, hogy a teljes életmüvet vegyük-e a gyüjtés alapjául, vagy iktassunk be szürőket.

A korpusz kiválasztása nemcsak mennyiségi, de módszertani szempontból is számos kérdést vet fel. Lehet korlátozni a gyüjtést a müfajok tekintetében. Elképzelhetö, hogy csak a regények és elbeszélések névkincsét gyüjtjük ki, esetleg még a színmüvekét, de például A magyar nemzet története regényes rajzokban címü kétkötetes munkát kihagyhatjuk, hiszen ez gyakorlatilag lexikonszerü feldolgozást igényel a szinte kizárólag valós történelmi szereplők, helyszínek bemutatása miatt. Igaz, a névhasználati kérdések sok érdekes problémát vetnek fel, például a vezérek vagy Árpád fiainak nevei kapcsán is. Ugyancsak meggondolandó lehet még az Írói arcképek és más korrajzot adó írások vagy a cikkek feldolgozása.

Az előforduló névadatok számbavétele több ezer személy-, hely- és egyéb név kigyüjtését jelenti a névfajták teljes körü figyelembevételével, de lehet szükíteni a kört, például a mücímek kihagyásával. Felmerülhet, hogy az intertextuális neveket nem vesszük fel a szótárba, itt azonban mérlegelni kell, hogy a névadás, névhasználat mely eseteiben érdemes ettől eltérni.

Már a gyüjtési fázisban sok kérdést el lehet és kell dönteni, hogy jól kezelhető anyag álljon rendelkezésünkre mind a mennyiség, mind az áttekinthetöség szempontjából. Az elektronikus, illetőleg digitális formában fellelhető szövegekböl való keresés még számos problémát rejt. Például a CD-ROM és ennek online változata esetében a kis- és nagybetű megkülönböztetése hiányzik, a szóalakok nehezen különíthetők el, a szövegben pedig nincsenek lapszámok. 
5.3. Filológiai szempontok. Fontos a gyüjtés alapjául szolgáló szövegek hitelessége. Ezért a kiindulást az ún. szövegkritikai kiadások textusai képezik, ezek alapján tudjuk megadni az elöfordulási helyet, az ún. lokuszt, hogy az adatok egyértelmüen azonosíthatók és visszakereshetők legyenek.

Közismert, hogy az 1962-től indult, NAGY Miklós és LengYel BALÁzs gondozásában megjelenő szövegkritikai kiadások elvei, gyakorlata időközben változtak. 2004-től EISEMANN GYÖRGY vezeti a további kötetek kritikai kiadásra való előkészítésének munkálatait. Az adatmennyiség miatt feltétlenül szükség van a szövegek digitális hozzáférhetöségére, és természetesen megfelelő informatikai háttérre is. A Jókai-szövegek nagy része a MEK anyagában olvasható. Ezek általában a szövegkritikai kiadásokon alapulnak, akárcsak az Unikornis-kötetek és az Arcanum CD-ROM-ján található korpusz is. A névanyag kigyüjtése és a címszójegyzék összeállítása során ez utóbbiak azonban fenntartásokkal kezelendők, a lokuszokat és a kritikai kiadások jegyzetanyagát a nyomtatott változatok alapján érdemes megadni.

5.4. Címszóproblémák. A tulajdonnevek - elsősorban személy- és helynevek - esetében is meg kell határozni a ma leginkább használatos, illetőleg ismert szóalakot, írásváltozatot, ami a címszó lehet. A kritikai kiadás szerkesztői minden kötet esetében eldöntötték a benne elöforduló nevek írását. Utólag lehet ezekkel a megoldásokkal vitatkozni, de az a legcélszerübb, hogy elfogadjuk a kritikai szövegkiadásban előforduló írásmódokat. Szükség esetén a szócikkben lehet utalni az írásváltozatokra. Természetesen az is számít, hogy Jókainál melyik alternáns a leggyakoribb, bár lehetnek fenntartásaink a szövegkiadások bizonytalansága miatt. Érdekes, hogy a regénycímben is megjelenő Rákóczy (Rákóczy fia) változatnál kétszer gyakoribb a ma közkeletü Rákóczi írásváltozat, és így egyértelmü, hogy ez utóbbi fog a szócikk élén állni.

Kétség esetén kénytelenek vagyunk a kritikai kiadást irányadónak tekinteni, bár éppen a nevek írása okán érte és érheti a legtöbb bírálat az egyes kötetek megoldásait, amelyeket inkább csak esetenként és megjegyzésszerüen érdemes figyelembe venni. Ebből következik, hogy a címszójegyzék összeállításánál sokkal körültekintőbben kell kezelni az alak- és írásváltozat fogalmát. A névváltozat külön kérdés, erről még később lesz szó. Külön kell választani a magyar névhasználatot és az idegen nyelvi alakokat is. Az idegen nevek helyesírása ugyancsak egyedi mérlegelést igényel a nyelvtől és Jókai írásmódjától függően is, de ez majd a szócikkírás feladata lesz.

Általában is igaz, hogy a címszók kiválasztásánál nem müködhetnek automatizmusok: a mai helyesírás, a szerzői akarat és az egyértelmü beazonosíthatóság szempontjait is figyelembe kell venni.

5.4.1. Azonos név - különböző névviselők. Mivel nem lexikont szerkesztünk, ha ugyanaz a név több szereplöt, helyszínt stb. jelöl, akkor a PetőfiSz. és többek között a MikesSz. gyakorlatát követve a különböző névviselök ugyanazon címszó alá kerülnek. Ennek megfelelően például a Kárpáthy címszó alatt fog szerepelni mintegy külön jelentésben Kárpáthy Abellinó vagy Béla, Kárpáthy János, Kárpáthy Jánosné és Kárpáthy Zoltán, valamint a szövegben még említett Kárpáthy-ősök ( Ábel, Ákos, Bertalan, Boldizsár, $\sim$ Dalia, $\sim$ Kupa, $\sim$ Ubul). A közös részt, vagyis a címszó jelölte névelemet jellel (tildével) helyettesítjük. 
Ugyanígy járunk el az azonos keresztnevűek esetében, így a Zoltán címszó alatt öt ,jelentést" is elkülöníthetünk. Természetesen az egyértelmüsítést a lokuszokon kívül példamondattal erősíthetjük. A szereplök, helyszínek stb. azonosítását a közszói szótárakban közölt szócikkek jelentéseinek mintájára kezeljük. Például:

Kárpáthy 1. Abellinó; 2. Béla; 3. János; 4. Zoltán.

Zoltán 1. (önállóan) Árpád vezér fia; 2. (önállóan) Petőfi fia; 3. 1. Kárpáthy ; 4. 1. Bárdy ; 5. 1. Kolompi .

5.4.2. A többelemű személynevek címszavasítása. A fenti példákból az is kiderül, hogy a családnévből és utónévből álló személynevek elemeit külön-külön címszavakhoz soroljuk. Az azonos tulajdonnevek (tulajdonnévi részek) által jelölt személyek azonosítására a jelentésszerkezet kialakításakor kerül sor: ha egy szereplő család- és keresztnévvel szerepel, akkor az értelmezése, azonosítása a családnév alatt történik, a keresztnévtől pedig visszautalunk a családnév szócikkére. Tehát például az Abellinótól, a Bélától, a Jánostól és a Zoltántól is utalunk a Kárpáthyhoz. Ha egy-egy név önállóan jelenik meg, akkor az adott címszó alatt értelmezzük, ahogy fentebb a Zoltán szócikkében láttuk.

A névkiegészítők (pl. [János] király) sem indokolják külön címszó felvételét. Viszont a ma kötőjelesen írandó címszók (pl. János-hegy) összetett szóként kezelendők, tehát külön szócikket kapnak. A Magdolna-arc, Nessus-ing, Medúza-fö, Herkules-alkat típusú szóösszetételek nem kerülhetnek a névszótárba, mivel ezek nem minősülnek tulajdonnévnek, bár tulajdonnevet tartalmaznak. A kettős, esetleg hármas keresztnevek (pl. Ferenc József, Lajos Fülöp) egységét nem bontjuk meg, a címszó tehát Ferenc József, illetőleg Lajos Fülöp lesz.

5.4.3. A többelemü földrajzi és egyéb nevek címszavasítása. A több elemből álló földrajzi nevek, címek, intézménynevek és egyéb tulajdonnevek is egy egységként kezelendők, és a mai nyelvi használat, valamint helyesírás szerint vesszük fel őket címszónak. Például Rio de Janeiro Jókainál előfordul Rio Janeiro formában is, ezt feltüntetjük alakváltozatként, de a címszó az előfordulás számától függetlenül Rio de Janeiro lesz.

A Ferenc József-föld címszó is egyértelmü annak ellenére, hogy Jókainál csak kötőjel nélkül fordul elő ez a helynév. Mivel a címszó szótárba felvett írásmódja egyáltalán nem szerepel a korpuszban, szögletes zárójelbe tesszük, mellette a szócikkfejben feltüntetjük a Jókaitól leírt változatot a vonatkozó adatszámmal: [Ferenc József-föld] helynév Ferenc József föld 8.

5.4.4. Különböző nevek - azonos névviselők. Jókainál is gyakori, hogy ugyanazt a személyt vagy egyéb névviselöt különböző neveken említi. Ezekben az esetekben minden név más szócikkben jelenik meg, és az azonos értelmezések, a kölcsönös és keresztutalások révén derül ki az összefüggés, a többnevüség. A keresztnevek különböző alak- és becéző változatai is ide sorolhatók, például Jancsi - János, Katinka - Katalin vagy Evila - Evelina. Fontos, hogy hasonló nevet viselö különböző regényalakok teljesen külön kezelendők. Az Eveline az Evelina névváltozata, de a Kárpáthy Zoltán címü regény Eveline nevü szereplőjének semmi köze a Fekete gyémántok hősnőjéhez, aki névváltoztatással jutott az Evelina névhez. Ebből következik, hogy lesz Eveline és Evelina szócikk is egymástól függetlenül. 
5.5. A névfajták rendszere. A névszótár szempontjából kiemelt jelentősége van, hogy világos legyen, hogyan osztályozzuk, soroljuk be az egyes tulajdonneveket, milyen tulajdonnévfajtákat különítünk el. Ez elsősorban az értelmezéshez szükséges, hiszen itt a szófaji besorolás helyén a névfajta megadása áll.

Egyes esetekben több megoldás is lehetséges. Például a több müben, többször is előforduló Cicke szerepelhet egyszerủen mint kutyanév, hiszen egyértelmü, hogy állatnévről van szó, de megadhatjuk a magasabb kategóriát is, így Cicke állatnév, kutyanév állhat a szócikkfejben. Az is elképzelhető, hogy a Cicke címszó után csak az állatnév „szófaji” besorolást közöljük, és a szócikk törzsében az értelmező, azonosító részben fejtjük ki, hogy pontosan melyik állatfaj mely egyedéről van szó az egyes jelentésekben, pl. 'Kárpáthy János egyik fehér agara' vagy 'Jókaiék kutyája' stb.

A közszói szótárakban előforduló többszófajúságot névszótárunkban a több névfajtát reprezentáló nevek fogják képviselni (pl. Gyula I. személynév, II. helynév egy szócikken belül). Viszont ha az azonos névalakok homonimának kezelendők, akkor a Buda névadatok esetében $\mathbf{B u d a}^{1}$ helynévi és $\mathbf{B u d a}^{2}$ személynévi szócikkbe soroljuk őket két külön címszó alá. Mindehhez nyelv- és helytörténeti ismereteket is segítségül hívunk.

5.6. A névkategóriák az írói névadás szempontjából. Az íróinév-szótárban a névelméleti kérdések látensen kapnak helyet: a névfajta meghatározása mellett törekszünk annak meghatározására, hogy adott tulajdonnév valós vagy fiktív, ez utóbbin belül valószerü vagy valószerütlen, esetleg motivált név. Ha kétség merül fel, azt is közöljük.

Összességében elmondhatjuk, hogy a névszótárban a névelméleti kérdéseket a gyakorlatba ültetjük át, meghatározva egy-egy szereplő nevének a valósághoz való viszonyát.

Jókai különböző müveiben, tehát regényeiben, elbeszéléseiben is találkozunk valóságos személyek valóságos neveivel, akár az író által kitalált történetbe beemelt szereplöként is. Wesselényi báró például nemcsak történelmi alakként fordul elö, hanem a Kárpáthy Zoltán egyik fontos alakjaként is. A valóságos nevek alkalmazása fontos írói eszköz (vö. VÁCZINÉ TAKÁCS 2018: 62-66), a történet hihetőségének erősítésére helyszínek megadásakor különösen jellemzö (Bécs, Buda, Ferenc József-föld stb.). Az ilyen névadásra mindenképp utalni kell a szócikk értelmező részében.

Meg kell különböztetnünk azokat a valós vagy valódi neveket (J. Soltész 1979: 153), amelyek a valóságban is léteznek. Jókainál sem ritkák ezek a névalkalmazások, például a Kis Miska, Barna Sándor vagy Cicke név alkalmazásakor a történet reális voltának hangsúlyozása játszhatott szerepet. A szócikkbeli minősítés szempontjából ezek a nevek semlegesek.

Az intertextualitás az írói nevek viszonylatában, különösen névszótári feldolgozás esetében meglehetösen bonyolult (vö. VÁCZINÉ TAKÁCS 2018: 30-31). Korábban már utaltam rá, hogy többek között terjedelmi okokból lehetséges mellőzni őket, ügyelve arra, hogy lényeges összefüggések ne sikkadjanak el. A mitológiai vagy egyéb utalások is ebbe a körbe tartoznak. Annak ellenére, hogy Jókai írói világának fontos részei, a névrendszerét nem érintik. Ezeket a neveket szereplöi, helyszínei stb. megjelölésére nem használja, tehát nem sorolhatók Jókai írói nevei közé; elsősorban a nyelvhasználatát, szókincsét jellemzik.

A legkönnyebben a fiktív nevek rendszere látható át. A már említett létezö vagy valódi nevek az író névrendszerének elemei, de az ismert keresztnevek sokszor összekapcsolódnak költött családnevekkel, pl. Szentirmay Katinka, Hátszegi Lénárd, Topándy Samu, Lánghy Aranka. Ezért is célszerü a család- és az utóneveket külön besorolni. 
Jellegzetes a valószerü nevek köre, amelyek hangalakjuk és morfológiai jellemzőik alapján akár valós elnevezések is lehetnének, mégsem azok, pl. Szentirma, Prusznóc, Kokánfalva, Körössziget, Kárpáthy, Tímea. Az további kérdéseket vet föl, hogy néhányuk a mai névkincsbe már be is épült, és csak kevesen tudják, hogy Jókainak köszönhetjük őket.

A valószerütlen nevek megalkotásában a képzelet jut nagyobb szerephez; a személyneveknél a jellemfestés, az irónia vagy a humor is megjelenik a hangalak és a jelentés viszonyában, pl. Otthon, Mindenváró Adám, Bogozy, Tuhutum vármegye.

A névstilisztikai megjegyzések - ahogy erre már utaltam - általában az értelmezésben kapnak helyet, de esetenként a szócikk elejére is kerülhetnek.

5.7. Az utalások rendszere. Minden szótárban fontos helyet kapnak az utalások, még akkor is, ha sokan nem szeretik, hogy egyik szócikktől a másikig „,ide-oda küldözgetik őket”. Azokban az esetekben, amikor a helyesírási megoldások nehezítik a keresést, feltétlenül szükség van utalókra. A Jókai-névszótárban az alak- és írásváltozatok utaló címszóként szerepelnek, ha - ahogy az a lexikográfiai gyakorlatban megszokott - az utalt címszótól betürendileg távolabb kerülnek.

Szótárunkban a legjellemzőbb utalástípus az, amikor a személynév egyik elemétől, jellemzően a keresztnévtől utalunk a másik elemre, vagyis a családnévre. Erről fentebb már volt szó (pl. Zoltán 1. Kárpáthy).

Amikor arra kell felhívni a figyelmet, hogy a szócikkben tárgyalt név egy másik szócikk tárgyával függ össze, akkor kölcsönös ,,vö.” kapcsolja össze őket, például a több néven említett személyeknél, helységeknél. Tehát névváltoztatásnál (pl. Fekete gyémántok) a már említett Evelina névhez tartozó szócikk végén utalunk az eredeti Evila névre és viszont. A Kárpáthy Zoltánban szereplö Eveline egyikkel sincs összefüggésben, így nem kapcsoljuk össze utalással a két nevet. Ez az alak más néven Köcserepyné, tehát ez utóbbi címszóra utalunk kölcsönös „,vö.”-vel az érintett szócikkvégeken. Az Akik kétszer halnak meg-beli Prusznóc falu nevéről szóló szócikk végén ugyancsak „,vö.” mutat a magyarított Petröcfalva név szócikkére és viszont (vö. T. SOMOGYI-TINER 2017: 70). A becéző formákat is mutató fő névváltozat végén ugyanez irányít a különböző névváltozatokhoz, pl. János vö. Jancsi, Jankó. Mivel a Jancsi és Jankó stb. értelmezésében szerepel, hogy 'a János férfinév becézö alakja', sőt a legtöbbször az is kiderül, melyik János nevü szereplöröl van szó, a szótárhasználó könnyen tájékozódhat az összefüggésekről, nincs szükség egyértelmü utalásra. Természetesen az is előfordulhat, hogy valamely szereplö csak becenéven említtetik; ilyenkor nincs is mire utalni.

5.8. A szócikkek felépítése, tartalmi része. Az utalókat leszámítva a szócikkek felépítése minden szócikk esetében állandó. A szócikkfejben címszó, a névfajta meghatározása, alak- és írásváltozat(ok), szóalak(ok), szóelőfordulás(ok) követik egymást, mindegyik után a megfelelő számadattal.

A szócikktörzsben kapnak helyet az értelmezések, azonosítások, ahogy a közszói szócikkekben a jelentések. A megfelelő példa mellett állhat stílusminősítés és a névkategória megjelölése. Ezek után közöljük a szövegkörnyezetet (példamondatot) és az előfordulás helyét a megfelelő kóddal, ami a mü rövidítéséből és általában a kritikai kiadás megfelelő kötetének lapszámából tevődik össze. Az esetleges utalások (1., vö.) értelemszerủen az egyes jelentések végén vagy a szócikkvégen találhatók. 
A következőkben a szemléltetésül hozott nagyon egyszerü példák pontos lokuszaitól a kódolás jelenlegi kidolgozatlansága, illetve az elsődleges keresés esetleges pontatlansága miatt most eltekintünk. Az idézetek a Kárpáthy Zoltán, A kőszívü ember fiai, Az elátkozott család és Az arany ember című regényekből valók.

Kárpátfalva költött helynév 47 : -Ø 6, - 't 3, -’n 15, - 'ra 22, - 'ról 3

'A Kárpáthy család legősibb birtoka'. [...] képzeletében már Kárpátfalva urának látja magát ismét. (KZ)

Lánghy költött családnév 9

1. Bertalan. 'Hazafias érzelmü tiszteletes.' Neve heves vérmérsékletére utaló motivált név. az öreg kurucot, ahogy tiszteletes Lánghy Bertalan uramat tisztelni szokták heves magaviseletéért. (KEF)

2. Aranka .'L.B. leánya, Baradlay Ödön jegyese, majd felesége.' Baradlayné vezeté kézen fogva az ünnepélyes vendégsereg elé a kért menyasszonyt: - Lánghy Arankát. (KEF)

3. gróf. 'Csak családnévvel említett előkelő személy'. Viktor násznagyául Lánghy gróf volt meghívva, a környék leggazdagabb föura. (ECs)

Rio de Janeiro helynév 7 || Rio de Janeiro 2 || Rio de janeiro 3 || Rio Janeiro 1| Rio janeiro 1: -Ø 1, - 'ba 1, - 'ban 1, - ’ból 2, -’ig 2

'Brazília legnagyobb városa, 1763-1960 között fővárosa.' [...] tanultam én geográfiát:

Brazília fóvárosa Rio Janeiro. (AE)

6. Az íróinév-szótár feladata és célja. Az íróinév-szótárak alapvetően az írói névadás feldolgozására hivatottak. Ennek a magyar névkutatásból még hiányzó speciális íróiszótártípusnak a feladata, hogy szócikkszerűen mutassa be az adott író névrendszerét, névadásinévhasználati jellegzetességeit a lexikográfia sajátos eszközeivel. A címszavak kiválasztását és a szócikkek struktúrájának kialakítását illetően megfelelően kell érvényesítenie mind a névtani, mind a lexikográfiai, mind a filológiai szempontokat, számot adva a névanyag gazdagságáról mind a mennyiséget, mind a változatosságot illetően. A cél az, hogy az írói szótárak legjobb hagyományait ötvözze az íróinév-kutatás legfontosabb eredményeivel, feltárva egy-egy író vagy mü teljes névrendszerét. Szócikkeiből kell, hogy összeálljon az adott író életmúvének vagy egy-egy alkotásának, esetleg egy irodalmi közösségnek a névrendszere.

\section{Felhasznált források}

AranySz. = Arany-szótár. Arany János költöi nyelvének szókészlete 1-3. Szerk. BEKE JózSEF. Anyanyelvápolók Szövetsége - Inter, Budapest, 2017.

BalassiSz. $=$ JAKAB LÁszLó - BöLCSKeI ANDRÁs, Balassi-szótár. Számítógépes nyelvtörténeti adattár 8. KLTE, Debrecen, 2000.

Balázsi József AtTila - Kiss GÁBor 2020. Jókai-enciklopédia. Szavak, kifejezések magyarázata és személyek, földrajzi helyek, történelmi események bemutatása. A Magyar Nyelv Kézikönyvei 32. Tinta Könyvkiadó, Budapest. 
BánkBSz. = Bánk bán-szótár. Katona József Bánk bán c. drámájának szókészlete. Szerk. BeKE JózSEF. Katona József Társaság - Kecskeméti Lapok, Kecskemét, 1991.

Boda István KáROly - PoRKoláB Judit 2009-2012. Interaktív konkordancia szótár Radnóti Miklós verseiböl. Debrecen. http://www.inf.unideb.hu/ bodai/concord2/concord.html (jelenleg nem elérhetö)

CsokSzkt. $=$ Csokonai-szókincstár 1-3. Szerk. JAKAB LÁszLó et al. KLTE - Debreceni Egyetemi Kiadó, Debrecen, 1993-2016.

Jackson, James Beaumont 1909. A Dictionary of the Proper Names of the Old and New Testament Scriptures, Being and Accurate and Literal Translation from the Original Tongues. Loizeaux Brothers, New York.

Jókai Mór összes müvei. CD-ROM. 2001. Arcanum Kft. - Unikornis Kiadó, Budapest.

JókaiSz. = Balázs Géza - P. Eöry Vilma - Kiss Gábor - J. Soltész Katalin - T. Somogyi Magda, Jókai-szótár 1-2. Unikornis Kiadó, Budapest, [1994].

JuhászSz. = Juhász Gyula költői nyelvének szótára. Szerk. BENKö LÁszLó. Akadémiai Kiadó, Budapest, 1972.

Lemprière, John 1788. Bibliotheca Classica (Classical Dictionary containing a full Account of all the Proper Names mentioned in Ancient Authors). T. Cadell, Reading.

MikesSz. = Mikes-szótár. Szerk. KIss MARGIT. MTA Bölcsészettudományi Kutatóközpont Irodalomtudományi Intézet, Budapest, 2013. http://mikesszotar.iti.mta.hu/ (2020. 11. 20.)

Parrott, Jeremy 2004. Change all the names. A critical onomasticon of characternyms in the works of Samuel Beckett. The Kakapo Press, Szeged.

PetőfiSz. = Petöfi-szótár. Petöfi Sándor életmüvének szókészlete 1-4. Szerk. J. Soltész Katalin Szabó Dénes - Wacha ImRe. Akadémiai Kiadó, Budapest, 1973-1987.

RadnótiSz. = Radnóti-szótár. Radnóti Miklós költöi nyelvének szókészlete. Szerk. BeKe József. Argumentum Könyvkiadó, Budapest, 2009.

ToldiSz. = PÁsztor EmiL, Toldi-szótár. Arany János Toldijának szókészlete. Tankönyvkiadó, Budapest, 1986.

Tótfalusi István 1992/1994. Irodalmi alakok lexikona. Móra Ferenc Könyvkiadó, Budapest.

Tótfalusi István 1993. Ki kicsoda az antik mítoszokban. Móra Ferenc Könyvkiadó, Budapest.

Tótfalusi István 1994a. Ki kicsoda Shakespeare világában. Móra Ferenc Könyvkiadó, Budapest.

Tótfalusi István 1994b. Ki kicsoda Shakespeare müveiben. Anno Kiadó, Budapest.

Tótfalusi István 1995. Ki kicsoda a Bibliában. Móra Ferenc Könyvkiadó, Budapest.

Tótfalusi István 1998. Irodalmi alakok lexikona. Bővített kiadás. Anno Kiadó, Budapest.

Tótfalusi István 2010-2011. Irodalmi alakok nagy lexikona 1-2. Argumentum Kiadó, Budapest.

ZrínyiSz. = Zrínyi-szótár. Zrínyi Miklós életmüvének magyar szókészlete. Szerk. BeKe JózSEF. Zrínyikönyvtár 5. Argumentum Kiadó, Budapest, 2004.

\section{Hivatkozott irodalom}

ÁDÁm ANIKÓ 1992. Kosztolányi a nevekröl. Összeállítás Kosztolányi írásaiból. Helikon Irodalomtudományi Szemle 1992/3-4: 389-399.

BenKő László 1979. Az irói szótár. Akadémiai Kiadó, Budapest.

BÜKY LÁszLó 1989. A személynevek stílushatása a költői nyelvben. In: BALOGH LAJOs - ÖRDÖG FERENC szerk., Névtudomány és müvelödéstörténet. A IV. magyar névtudományi konferencia 
elöadásai Pais Dezső születésének 100. évfordulóján (Zalaegerszeg, 1986. október 8-10.). A Magyar Nyelvtudományi Társaság Kiadványai 183. Magyar Nyelvtudományi Társaság, Budapest. 294-297.

BÜKY LÁsZló 2008. Személynevek felbontása és felépítése a költői nyelvben. In: BöLCSKEI ANDREA N. Császi Ildikó szerk., Név és valóság. A VI. Magyar Névtudományi Konferencia elöadásai. Balatonszárszó, 2007. június 22-24. A Károli Gáspár Református Egyetem Magyar Nyelvtudományi Tanszékének Kiadványai 1. Károli Gáspár Református Egyetem Magyar Nyelvtudományi Tanszék, Budapest. 540-547.

BüKy LÁszLó 2010. Beke József szerk., Radnóti-szótár. Radnóti Miklós költői nyelvének szókészlete. Magyar Nyelv 106: 372-380.

FÁBIÁN ZsUZSANNA 2015. A szótár, illetve a lexikon és az enciklopédia megkülönböztetése az „enciklopédikus szótár" müfajának tükrében. In: FÁBIÁN ZsuzsANNA - Szöllösy Éva szerk., Szótár, lexikon, enciklopédia. Kérdések és feladatok. Segédkönyvek a nyelvészet tanulmányozásához 172. Tinta Könyvkiadó, Budapest. 17-38.

FARKAs TAMÁs 2006. Jeremy Parrott: Change all the names. A Samuel Beckett Onomasticon. Névtani Értesitö 28: 283-284.

FARKAS TAMÁs 2007. Kárpáti, Kárpáthy és a Kárpáti-k. Egy új keletű magyar családnév művelődéstörténete. In: Hoffmann IstvÁN - JuHÁsz Dezső szerk., Nyelvi identitás és a nyelv dimenziói. Nyelv, nemzet, identitás III. Nemzetközi Magyarságtudományi Társaság, Debrecen-Budapest. $147-164$.

FARKAS TAMÁS 2014. A névtelenség és a megnevezés alapkérdéseiről. In: BAUKO JÁNOS - BENYOvsZKY KrIszTiÁn szerk., A nevek szemiotikája. Nyitrai Konstantin Filozófus Egyetem Közép-Európai Tanulmányok Kara - Magyar Szemiotikai Társaság, Nyitra-Budapest. 124-138.

FARKAS TAMÁs 2020. A tulajdonnevek szótári feldolgozásának alapkérdései. In: FARKAS TAMÁs - SLíz Mariann szerk., Tulajdonnevek és szótárak. ELTE Magyar Nyelvtudományi és Finnugor IntézetMagyar Nyelvtudományi Társaság, Budapest. 11-36. https://doi.org/10.26546/4892373.2

Goda GÉza 1951. Jókai-szó- és szólástár. Magyar Nyelvőr 75: 421-424.

Heltainé Nagy Erzsébet 1998. A nevek és az elmúlás stilisztikája Sinka István költészetében. In: SzATHMÁRI IstVÁN szerk., Stilisztika és gyakorlat. Nemzeti Tankönyvkiadó, Budapest. 84-98.

Heltainé NAGy ERzsÉBEt 2010. A tulajdonnév jelentése és stilisztikája kognitív megközelítésben - a sinkai személynevekben. Magyar Nyelvör 134: 283-297.

KAPOSI JózsEF 1985. Egy Jókai-regény személynevei. Névtani Értesítő 10: 127-131.

KéFER PIros 2001. Irodalmi névadás Jókai Mór: Az új földesúr címủ müvében. Névtani Értesítő 23: 81-91.

Kiss Margit 2012. A digitális Mikes-szótár. Magyar Tudomány 173: 279-284.

Kornyáné Szoboszlay Ágnes 1995. Tulajdonnevek Németh László regényeiben és társadalmi drámáiban (Egy írói névszótár terve). Névtani Értesitö 17: 37-44.

KoRnYÁNÉ SzoBoszlay ÁgNes 1997. Játék a nevekkel (Németh László névadási indítékairól). In: B. Gergely Piroska - Hajdú Mihály szerk., Az V. Magyar Névtudományi Konferencia előadásai. (Miskolc 1995. augusztus 28-30.) A Magyar Nyelvtudományi Társaság Kiadványai 209. Magyar Nyelvtudományi Társaság - Miskolci Egyetem Bölcsészettudományi Intézet, Budapest-Miskolc. 541-549.

KornyÁné Szoboszlay Ágnes 2008. Magyarország antonomáziája Petőfi költészetében és prózájában. In: Bölcskei ANDrea - N. Császi IldiKó szerk., Név és valóság. A VI. Magyar Névtudományi Konferencia elöadásai. Balatonszárszó, 2007. június 22-24. A Károli Gáspár Református Egyetem 
Magyar Nyelvtudományi Tanszékének Kiadványai 1. Károli Gáspár Református Egyetem Magyar Nyelvtudományi Tanszék, Budapest. 564-569.

KoRnYÁNÉ SzoBoszlay ÁGNES 2014. Németh László írói névadásáról. Visszatekintés és tanulságok. Magyar Nyelvjárások 52: 209-220.

Kovalovszky Miklós 1934. Az irodalmi névadás. A Magyar Nyelvtudományi Társaság Kiadványai 34. Magyar Nyelvtudományi Társaság, Budapest.

Kutasi Zsuzsanna 1991. Jókai Mór, Egy az Isten. In: Hajdú Minály szerk., Dolgozatok az írói névadásról I. Magyar Névtani Dolgozatok 93. ELTE Magyar Nyelvészeti Tanszékcsoport Névkutató Munkaközössége, Budapest. 47-56.

MÁRTONFI AtTILA 2014. Számitógép és irói szótár - különös tekintettel a készülö József Attila-szótárra. Magyar Nyelv 110: 30-46.

MÁrtonfi Attila 2015. Kisenciklopédia a szótárban? A tulajdonnevek (írói) szótári kidolgozása. In: FÁBIÁn ZsUZSANNA - Szöllösy Éva szerk., Szótár, lexikon, enciklopédia. Kérdések és feladatok. Segédkönyvek a nyelvészet tanulmányozásához 172. Tinta Könyvkiadó, Budapest. 85-99.

NaGy Miklós 1995. Jókai-szótár 1-2. Irodalomtudományi Közlemények 99: 135-138.

NAGY MikLós 1999. Kárpáthy Zoltántól Topándi Samuig. Egy fejezet Jókai írói névadásának történetéböl. Névtani Értesitö 21: 293-299.

NAGY MikLós 2001a. Szilárdy Leandertől Mócli bérkocsisig. (Jókai írói névadásáról.) Forrás 33: 68-77.

NAGY MikLós 2001b. Az írói névadás Jókai késői regényeiben. Irodalomtörténet 4: 554-563.

РÁJ Gréta 2014. Poliszém jelentésszerkezetek Kosztolányi Dezső Édes Anna címü regényében. Névtani Értesitö 36: 159-167.

J. Soltész Katalin 1958. Az irodalmi helynévadás. Magyar Nyelvőr 82: 50-61.

J. Soltész KatAlin 1964. Névdivat és irodalmi névadás. Magyar Nyelvőr 88: 285-294.

J. Soltész Katalin 1979. A tulajdonnév funkciója és jelentése. Akadémiai Kiadó, Budapest.

J. Soltész Katalin 1982. Arany János névvilága. Magyar Nyelvőr 106: 281-293.

Somogyi GéZa 1917. Ami még nincs, de kellene. Magyar Nyelvőr 46: 104-108.

T. Somogyi Magda 2007. Az írói névadás és a nemzettudat Babits Mihály Halálfiai c. regényében. In: MATıcsÁK SÁNDOR et al. szerk., Nyelv, nemzet, identitás I. Nemzetközi Magyarságtudományi Társaság, Debrecen-Budapest. 359-367.

T. Somogyi MAGdA 2009. Családnév-változtatás az írói névadásban. In: FARKAS TAMÁs - KozMA IsTvÁN szerk., A családnév-változtatások történetei időben, térben, társadalomban. Gondolat Kiadó - Magyar Nyelvtudományi Társaság, Budapest. 313-331.

T. Somogy MAGDa 2014. A tulajdonnevek helye az írói szótárakban (Gondolatok a készülő Mikesszótár kapcsán). In: Bauko János - BenYovszky Krisztián szerk., A nevek szemiotikája. Nyitrai Konstantin Filozófus Egyetem Közép-Európai Tanulmányok Kara - Magyar Szemiotikai Társaság, Nyitra-Budapest. 166-183.

T. Somogyi Magda 2015. Az írói névadás vizsgálata. In: Farkas TAMÁs - Slíz Mariann szerk., $M a-$ gyar névkutatás a 21. század elején. Magyar Nyelvtudományi Társaság - ELTE Magyar Nyelvtudományi és Finnugor Intézet, Budapest. 207-226.

T. Somogyi MAgDA - Tiner TiBor 2017. Topánfalvától az Északi pólusig - A földrajzi nevek Jókai mủveiben. In: Benỏ AtTILA et al. szerk., Tudományköziség és magyarságtudomány a nyelvi dimenziók tükrében. Termini Egyesület, Törökbálint. 65-75.

SzATHMÁRI IstvÁn 1993. Szabó Pál a nevekröl, a névdivatról. Névtani Értesítő 15: 293-295.

K. Szoboszlay Ágnes 1992. Realitás és fikció az írói-irodalmi névadásban. Névtani Értesitő 14: 69-74. 
VÁCZINÉ TaKÁcs Edit 2018. Az írói névadás sajátosságai. Karinthy Frigyes müvei alapján. Magyar Névtani Értekezések 6. Magyar Nyelvtudományi Társaság - ELTE BTK Magyar Nyelvtörténeti, Szociolingvisztikai, Dialektológiai Tanszék, Budapest. https://doi.org/10.26546/4890065

VARGA JózsefNÉ 2004. Galgóczi Erzsébet: Ez a hét még nehéz lesz. - A realitás és a fikció szerepe az írói névadásban. Névtani Értesítő 26: 160-170.

VITÁNYI BORBÁla 1982. Valóságos családnevek Tömörkény műveiben. Névtani Értesitö 7: 103-109.

VitÁNYI Borbála 1985. Valóság és képzelet az irodalmi névadásban. In: BéKÉSI IMRE szerk., Név és névkutatás. A Magyar Nyelvtudományi Társaság Kiadványai 170. Magyar Nyelvtudományi Társaság, Budapest. 223-231.

WACHA ImRe 1961. A magyar írói szótárak kérdése. Magyar Nyelvőr 85: 189-203.

Wacha Imre 1994. Utószó a Jókai-szótárhoz. In: Balázs GÉzA - P. EÖRY VILMA - Kiss GÁBor - J. Soltész Katalin - T. Somogyi Magda, Jókai-szótár 1-2. Unikornis Kiadó, Budapest. 2: 437-446.

T. Somogyi Magda

ORCID: https://orcid.org/0000-0002-7665-3660

ELTE Eötvös Loránd Tudományegyetem Bölcsészettudományi Kar

\section{Magda T. Somogyi, Some questions of dictionaries on literary names raised by the ongoing project of compiling the name dictionary of Jókai's works}

The study reviews the main features of literary name-giving, author dictionaries, name dictionaries and literary name dictionaries, mainly based on Hungarian historical data and research results, highlighting key connections. It first reviews the research questions that arise in connection with literary names to examine to what extent they can and should be applied in the compilation of literary name dictionaries. The study details the types and editorial methods of Hungarian author dictionaries, and especially, how proper names are processed within these. It examines the antecedents of and connections between the dictionaries of Hungarian literary names currently being prepared or planned and offers overviews of the dictionaries of two scholars who wrote in English and the onomasticon of a contemporary English researcher. The paper then reviews lexicon-like works that list the names of literary heroes and which can be of use in the creation of literary name dictionaries. Finally, a plan for a dictionary of literary names, the Dictionary of Jókai's Literary Names is presented, highlighting its place among author dictionaries and onomastic works. The author emphasises the challenges that the 10-million-word oeuvre presents in collecting items and examines the difficulties of selecting entry headwords and philological, textual questions. The paper is closed with a few insights into the structure of the word entries being prepared, and data management issues that still need to be solved. 